\section{COMPOSITIONS OF QUACK} MEDICINES.

Roche's Embrocation, for the Fooping Cough-COlive oil sixteen ounces; oil of amber eight ounces, scented strong with oil of cloves.

Taylor's Remedy for Deafness. -Oil of almonds, one pound; bruised garlic two ounces: alkaret root, half an ounce: infuse, and strain.

Whitehead's Essence of Mustard.-Oil of turpentine; camphor; spirits of rosemary; to which is added four of mustard.

Rymey's Cordial Tincture.Capsicum ; camphor ; lesser cardamoms ; rhubarb ; aloes, and castor, in proof spirit, with a few drops of oil vitriol.

Bateman's Pectoral Drops.Sweet fennel seeds, two pounds eight ounces; aniseeds, one pound ; proof spirit, four gallons ; water, a sufficient quantity; distil ten gallons, to which add opium, seven ounces and four drachms; camphor, six ounces; prepared kali, one ounce; red coral, four ounces.

Freeman's Bathing Spirits.Solt soap, six pounds ; camphor, eight ounces; rectified spirits of wine; water, of each three galIons : colour with Daffy's elixir.

\section{MISCELIANEOUS.}

Progress of Science.

Mortar-M. Berthier has lately given an analysis of the Roman cement of Parker and Wyatt, of
London. According to him it is composed cf

$$
\begin{aligned}
& \text { Carbonate Lime........657 } \\
& \text { —_ Magnesia ......605 } \\
& \text { - } \begin{array}{l}
\text { Iron............070 } \\
\hline
\end{array} \\
& \text { Clay Silicia............ } 180 \\
& \text { Clumnia ............066 } \\
& 1.000
\end{aligned}
$$

Berthier thinks, that with one part of common plastic clay, and two and a half of chalk by weight, a very good hydraulic lime could be made, which would set as speedily as the English one; but it is not probable, he allows, that we can obtain by mixtures bydranlic lime, which will acquire as great hardness and solidity $i$ is the natural mortar, because these qualities depend not only on the composition, but also on a state of compactness. The greater density the material possesses, and if it slake without changing' its volume, the greater facility will its particles have in becoming aggregated, and the less shrinking will there be during its consolidation. Berthier has drawn the following conclusions from a namerous set of experiments. A lime-stone which contains 6 per cent. of clay affords a lime already perceptibly hydraulic. When the lime amounts to from 15 to $20 \mathrm{per}$ cent. it is very hydraulic, and when from 25 to 30 , it sets almost instantly, and may therefore be considered as Roman cement. He conceives that the iron and manganese have no effect whatever in occasioning the hardening.

In a mortar, which owes its solidity to the adhesion of the lime to the alloys, or subtances with which it is mixed, there is evidently an advantage in multiplying as much as possible the 
surfaces of contact. Thus, alloys at each step, but he found it imwith large grains, do not afford possible to reach the mouth. mortars so solid as the pulverulent ones, because there are spaces filled with pure lime, which do not present the same resistance to fracture as the other parts. On the contrary, alloys in powder, though they present the greatest surface, yet require a very large proportion of lime. To obtain, then, with the smallest possible quantity of lime, mortars possessing the greatest solidity, alloys must be used, containing particles of different sizes, avoiding always the mixture of argillaceous substances, which form a paste with water, hut have no coherence. These opinions have been put to the test of experiment on a large scale, the sand usually employed at Paris affording a better mortar when merely washed, than when the fine particles are removed by a sieve.

Volcano of Barren Islands.This volcano was visited by Captain Webster in March last. When entering the bay they were assailed at the distance of 100 yards from the shore, with puffs of warm wind, and on dipping their fingers into the water it was found to be quite hot. The stones on shore were also warm, and the water bubbling all around them. Having landed, he ascended the precipice towards the cone, which appeared to be abont a quarter of a mile distant. The diameter of the base of the volcano is about 300 yards, and about 30 at the top, and there issued from it continually a white thin smoke. In order to examine the crater, Captain Webster ascended 30 or 40 yards, sinking ancle deep in ashes

Matrix of the Brazilian Diamond.-In Mr. Heuland's collection there is a Brazilian diamond imbedded in brown iron ore. Another in the same matter is in the possession of M. Schuch, librarian to the Crown Princess of Portugal. Eschwege has in his cabinet a mass of brown iron ore, in which there is a diamond in a cavity of a green mineral, supposed to be arseniate of iron. From these facts, he infers that the matrix, or original repository. of the diamond of Brazil, is brown iron ore, which occurs in beds of slaty quartzose micaceous iron ore, or in beds composed of iron glance and magnetic iron ore, named by him Itabirite.

\section{TABLE TALK.}

Dreadful Accident from Firedamp. - Thirty-two l'ersons killed. - It is this week our painful duty to record one of those heartwounding events, which, notwithstanding the luminous discoveries and improvements lately made in the sciences, and particularly in that which is more immediately connected with the art of mining. seems inseparable from those illfated mortals whose province it is to explore the bowels of the earth. On Monday night last, the town of Whitehaven was thrown into the utmost agitation, by an awful explosion of fire-damp, from the William Pitt (a name of disastrous import)-a coal-mine belonging to the Earl of Lonsdale, where it was known, that a considerable number of colliers were at the moment employed in the work- 